\title{
UGDYTOJŲ IŠ PAAUGLIŲ TARDYMO IZOLIATORIAUS IR PATAISOS NAMŲ FIZINIO AKTYVUMO IR SAVIJAUTOS SĄSAJOS
}

\author{
Laimutè Kardeliené ${ }^{1}$, Donatas Lengvinas ${ }^{2}$, Sandra Bardauskien $\dot{e}^{3}$ \\ Lietuvos kūno kultūros akademijal ${ }^{1}$, Kaunas, Klaipédos universitetas, Klaipéda ${ }^{2}$, \\ Kauno medicinos universitetas ${ }^{3}$, Kaunas, Lietuva
}

Laimutė Kardelienė. Socialinių mokslų (edukologijos) daktarė. Lietuvos kūno kultūros akademijos Sveikatos ir fizinio aktyvumo katedros docentè. Mokslinių tyrimų kryptys — kūno kultūros ugdymo aksiologija ir tyrimų metodologija; profesinė socializacija.

\section{SANTRAUKA}

Tyrimu siekta ivvertinti ugdytoju iš paangliu tardymo izoliatoriaus ir pataisos namu fizinį aktyvuma, atskleisti jo sqsajas su savijautos rodikliais.

Tiriamaja imti, tiriant visq generaline visuma, sudare 84 tiriamieji (31 vyras ir 53 moterys).

Taikant apklausos raštu metodq atskleistas toks ugdytoju profesinès socializacijos kontekstas: fizinis aktyvumas laisvalaikiu, savijauta ir finansine padètis. Tiriamuju savijautq apibüdino atsakyti klausimai apie subjektyvu sveikatos vertinima ir rūpinimasi ja. Taip pat teirautasi apie rūkyma ir kaip dažnai per paskutinius 12 mènesiu juos vargino ¿vairūs psichosomatiniai ir somatiniai negalavimai.

Tyrimo rezultatai atskleide, kad fiziškai aktyvesni ugdytojai (vyrai ir moterys) iš paangliu tardymo izoliatoriaus ir pataisos namu rečiau nei mažiau aktyvūs išgyvena kylančia itampa, rečiau patiria ỉvairius psichosomatinius, somatinius negalavimus ir mano, kad gyvena kaip dauguma šeimu Lietuvoje. Pastarojo teiginio atžvilgiu geriau savo finansine padèti, lyginant su kitais Lietuvos gyventojais, vertina mažiau fiziškai aktyvūs tiriamieji.

Fiziškai aktyvesnès moterys ir vyrai geriau nei mažiau aktyvūs vertina savo sveikata, tačiau fiziškai aktyvesni vyrai, skirtingai nei moterys, rečiau linke ja rüpintis.

Nenustatyta teigiamo ryšio tarp fizinio aktyvumo ir rūkymo. Tai rodo, kad gerinant asmens savijauta, be fizinio aktyvumo, turètu büti taikomos ir kitos sveikq gyvensena propaguojančios profilaktinio poveikio priemonès.

Raktažodžiai: fizinis aktyvumas, savijauta, sveikatos vertinimas.

\section{IVADAS}

$\check{\mathrm{S}}$ is laikmetis apibūdinamas kaip radikalios modernybès epocha. Tokioje aplinkoje neišvengiamas nerimas ir neapibrèžtumas. Atsiranda vis nauji alternatyvūs būdai asmeniui stiprinti savo sveikatą griebiantis įvairiu medikamentų, išbandant skirtingas dietas, užsiimant tradi- cinèmis ir netradicinėmis kūno kultūros saviugdos formomis ir būdais (Cavill et al., 2006).

Kūno kultūros ugdymo filosofai iškelia fizinio aktyvumo svarbą skatinant asmenis suvokti savo sveikatos stiprinimo, fizinio tobulejimo socialini vertingumą ir reikšmingumą (Schneider, Becker, 
2005). Aptariant suaugusių žmonių požiūrị i savo sveikatą kaip esminę vertybinę orientaciją galima iškelti fizini aktyvumą laisvalaikiu kaip sèkmingos profesinès karjeros sąlygą (Takao et la., 2003; Warburton et al., 2006).

Mokslininkai gilinasi į dirbančiujų fizinę saviugdą apskritai (Гуревич, Радиловская, 2003), atskleidžia sąsajas tarp bendrojo fizinio aktyvumo ir fizinio aktyvumo profesineje veikloje bei laisvalaikiu (Allender et al., 2008; Wolin, Bennett, 2008), aptaria ir fizini aktyvumą tik laisvalaikiu (Burton, Turrell, 2000). Kiti autoriai gilinasi i i ivairių sričiu specialistų bendraji fizini aktyvumą, iskaitant toki aktyvumą profesineje veikloje, namų ruošoje, judant ir laisvalaikiu (Reichert et al., 2007).

Aprašytoji situacija rodo, kad individualaus veikèjo fizini aktyvumą galima traktuoti kaip socialiai vertinga. Kadangi individas veikia tam tikroje erdveje ir laike, tai tyrimas planuotas remiantis struktūracijos teorija. Taip atsižvelgiama ir ị socialinius, ir i fizinius asmens veiklos suvaržymus, kuriu jis negali pakeisti (Giddens, 1984). Tačiau bet kurioje situacijoje individui prieinamas tik tam tikras veiksnumo realizavimo pasirinkimu rinkinys. Žinant, kad fizinis aktyvumas yra savijauta (fizinę, emocinę ir socialinę) stiprinantis veiksnys, gilintasi i paaugliu tardymo izoliatoriaus ir pataisos namų pareigūnų (ir kaip ugdytojų, ir kaip policijos pareigūnų) fizini aktyvumą ir savijautą. Mat jie atstovauja toms profesijoms, kurių veikla susijusi su nuolatine psichine ir fizine itampa - is šiu profesijų atstovų daug reikalaujama pagal pareigybinius igaliojimus, apribojančius jų iniciatyvą priimant sprendimus, jų sveikatą neigiamai veikia kylantys sunkumai pedagoginio bendravimo metu, nepasitenkinimas finansiniu atlygiu (Brown et al., 1999). Tokia darbinè situacija keičia ju požiūrị i profesinę veiklą (Burke, Mikkelsen, 2005; Buker, Wiecko, 2007), t. y. formuojasi ir negatyvi nuostata dèl prasižengusių paauglių ugdomosios veiklos tardymo izoliatoriuje bei pataisos namuose.

Atliktas tyrimas, kuriuo keltas probleminis klausimas: koks ugdytoju iš paaugliu tardymo izoliatoriaus ir pataisos namu fizinio aktyvumo ir savijautos ryšys profesinès veiklos požiūriu?

Tyrimo tikslas - atskleisti ugdytojų iš paauglių tardymo izoliatoriaus ir pataisos namų fizinio aktyvumo ir savijautos rodiklių sąsajas.

\section{TYRIMO METODIKA}

Tiriamųjų kontingentas ir metodai. Siekiant užsibrèžto tikslo, tyrimo metu sudaryta nepriklausoma imtis. Nustatytas ugdytoju iš tardymo izoliatoriaus ir pataisos namu (PnTI ugdytojai - toliau vartojamas trumpinys) fizinis aktyvumas laisvalaikiu kaip sèkminga profesinès veiklos prielaida. Tiriant generalinę visumą, imties tūri sudare 84 asmenys, dirbantys ugdomaji darbą (31 vyras ir 53 moterys), parinkti iš visų Lietuvoje esančių tokio tipo institucijų. Gilintasi i tirtu asmenu fizinio aktyvumo laisvalaikiu sąsajas su kitais tiriamojo objekto kintamaisiais, nes tiriamoji imtis reprezentuoja visą tokių darbuotojų generalinę aibę. Šis teiginys pagrindžiamas aukštu atsako į išdalytus klausimynus dažniu $93,3 \%$.

Tyrimas atliktas parengus klausimyną. Jị sudarantys klausimai ir teiginiai leido atskleisti toki ugdytoju profesinès socializacijos kontekstą: fizini aktyvumą laisvalaikiu, finansinę padèti, savijauta. Aiškintasi, kokios sąsajos dominuoja tarp tyrimo objekto kintamuju ir tyrimo dalyvių lyties.

Atsakymai i klausimą apie fizinio aktyvumo dažni laisvalaikiu leido suskirstyti tiriamuosius i dvi grupes, t. y. i fiziškai aktyvius ir mažai aktyvius. Fiziškai aktyviais îvardyti tie tiriamieji, kurie ne rečiau kaip 2-3 kartus per savaitę laisvalaikiu sportavo arba mankštinosi taip, kad suprakaituotų ir padažnėtų kvėpavimas. Tiriamuju finansinè padètis nustatyta pagal tai, kaip jie šią padèti vertina lygindamiesi su kitomis šeimomis Lietuvoje.

Tiriamujų savijauta paaiškejjo atsakius jiems i klausimus. Teirautasi, kaip jie apibūdintų savo sveikatos būklę pasirinkę vieną iš atsakymo variantų: gera, pakankamai gera, vidutiniška, pakankamai bloga ir bloga. Kitu klausimu teirautasi, ar jie rūpinasi savo sveikata. Pagal atsakymus tiriamieji suskirstyti i dvi grupes: nesirūpinantys savo sveikata (visai nesirūpina ar nesirūpina) ir besirūpinantys sveikata (šiek tiek rūpinasi ar labai rūpinasi). Taip pat klausta, kiek kartu per paskutinius 12 mènesiu jie peršalo ir dèl to sirgo (iskaitant ir gripa) taip, kad teko guleti lovoje ilgiau nei vieną dieną. Be to, aiškintasi, kiek kartu per tą patị laikotarpi jie lankèsi pas gydytoją (išskyrus odontologą), kaip dažnai rūko.

Gilinantis i tirtujų savijautą teirautasi apie psichosomatinius ir somatinius negalavimus, kurie vertinti naudojant 10 punktų skalę (Stock, Kramer, 2000). Tiriamujų klausta, kaip dažnai per paskutinius 12 mėnesių juos vargino minėti negalavimai. Pagal jų dažni tiriamieji suskirstyti i dvi grupes. Pirmai grupei priskirti asmenys, kuriu minèti negalavimai niekada nevargino arba retai 
vargino, antrai - tie, kuriuos tokie negalavimai dažnai ir labai dažnai vargino. Be to, kiekvieno tiriamojo psichosomatiniai ir somatiniai negalavimai įvertinti suminiu balu, tam ar kitam atsakymu variantui priskiriant atitinkamą balą: nuo 1 balo už atsakymą niekada, iki 4 balų už atsakymą labai dažnai. Negalavimų suminis balas leido sudaryti dvi tiriamuju grupes. Pirmai grupei priskirti asmenys, kuriuos įvairūs negalavimai vargino retai arba nevargino, o jų suminis balas buvo lygus ar mažesnis už medianą. Antrą grupę sudarè tie tiriamieji, kuriuos negalavimai vargino dažnai ir labai dažnai, ir balų suma buvo didesnè už medianą. Psichosomatinių ir somatinių negalavimų skalès teiginių vidinis suderinamumas patikrintas skaičiuojant Kronbacho alfa (Cronbach alpha) koeficientą, kuris šioje skalèje buvo 0,87 .

Tyrimo procedūros. Tyrimas atliktas 2009 metų balandžio__ birželio mènesiais, sutikus konkrečių institucijų administracijai. Tiriamieji informuoti apie tyrimo tikslą, paaiškinta, kaip pildyti klausimyna. Apklausoje vadovautasi etiniais ir teisiniais socialinio tyrimo principais. Siekiant anonimiškumo ir gautu duomenų objektyvumo vokas su klausimynu iteiktas kiekvienam, geranoriškai sutikusiam dalyvauti apklausoje. Be to, tiriamojo paprašyta palikti voką su užpildytu klausimynu specialiai tam įrengtoje vietoje.

Statistinè analizè. Tyrimo duomenims skaičiuoti taikyta SPSS for Windows 14 programa. Skaičiuotas kokybiniu požymiu pasiskirstymo dažnis procentais, o jų statistiniai ryšiai įvertinti taikant chi kvadrato kriterijų. Rezultatai laikyti statistiškai reikšmingais, jei paklaidos tikimybès reikšmè $\mathrm{p} \leq 0,05$.

\section{REZULTATAI}

Vienas iš asmens savijautos veiksnių - fizinis aktyvumas - atskleistas vadovaujantis tiriamuju atsakymais apie sportavimo ir mankštinimosi laisvalaikiu dažnį. Tyrimo duomenimis, $77,8 \%$ vyrų buvo fiziškai aktyvūs, t. y. fizinius pratimus jie atliko 2-3 kartus per savaitę ir dažniau. Moterys pagal ši tyrimo objekto kintamaji buvo fiziškai pasyvesnès $-52,0 \%(\mathrm{p}<0,02)$.

Atskleista, kad fiziškai aktyvesnès moterys labiau rūpinasi savo sveikata nei mažiau fiziškai aktyvios $(61,5$ ir $16,7 \%$; p < 0,001). Tarp vyrų fiksuotas atvirkštinis rezultatas: labiau savo sveikata rūpinasi mažiau fiziškai aktyvūs vyrai $(33,3 \%)$ nei aktyvūs $(23,8 \%)$. Fiziškai aktyvesni vyrai kiek dažniau savo sveikatą vertina gerai ir pakankamai gerai $(81,0$ ir $66,7 \%)$. Tokia pat tendencija pastebima ir tarp moteru $(65,4$ ir 50,0\%).

Kiti tiriamujų savijautos duomenys rodo, kad fiziškai aktyvūs vyrai $(33,3 \%)$ ir moterys $(41,7 \%)$, lyginant su mažai aktyviais (atitinkamai 50,0 ir $63,2 \%$ ) per praejjusius 12 mėnesių rečiau sirgo peršalimo ligomis (ar gripu) taip, kad tektų gulèti lovoje ilgiau nei vieną dieną.

Akcentuotina, kad fiziškai aktyvūs vyrai $(60,0 \%)$ ir moterys $(81,8 \%)$, lyginant su mažai aktyviais (atitinkamai 80,0 ir $94,1 \%$ ), per praèjusius 12 mènesių rečiau lankèsi ir pas gydytoją (išskyrus odontologą).

Tiriamujų atsakymai apie įvairius psichosomatinius ir somatinius negalavimais pateikti lentelëje.

Iš lentelëje pateiktų duomenų matyti, kad fiziškai aktyvesni vyrai ir moterys rečiau patiria ịvai-
Lentelè. Per praėjusius 12 mènesių nevarginusių psichosomatinių ir somatinių negalavimų raiška skirtingo fizinio aktyvumo grupèse $(\%)$

Pastaba. * - p $<0,05$, lyginant fiziškai aktyvių bei mažai aktyvių vyrų ir moterų duomenis.

\begin{tabular}{|l|c|c|c|c|}
\hline \multirow{2}{*}{ Tiriamieji } & \multicolumn{2}{|c|}{ Vyrai } & \multicolumn{2}{c|}{ Moterys } \\
\cline { 2 - 5 } & Aktyvūs & $\begin{array}{c}\text { Mažai } \\
\text { aktyvūs }\end{array}$ & Aktyvios & $\begin{array}{c}\text { Mažai } \\
\text { aktyvios }\end{array}$ \\
\hline Galvos skausmas & 14,3 & $0,0^{*}$ & 19,2 & $8,7^{*}$ \\
\hline Nerimas & 38,1 & 40,0 & 30,8 & $8,7^{*}$ \\
\hline Depresiškumas & 66,7 & 60,0 & 61,5 & $30,4^{*}$ \\
\hline Miego sutrikimas, nemiga & 33,3 & 40,0 & 34,6 & 22,7 \\
\hline Greitas širdies plakimas, galvos svaigimas & 61,9 & $40,0^{*}$ & 40,0 & $17,4^{*}$ \\
\hline Skrandžio negalavimai, remuo & 36,8 & $0,0^{*}$ & 30,8 & 31,8 \\
\hline Nugaros skausmai & 26,3 & $0,0^{*}$ & 61,5 & $31,8^{*}$ \\
\hline Sprando ar pečių skausmai & 28,6 & 20,0 & 53,8 & $26,1^{*}$ \\
\hline
\end{tabular}


rius psichosomatinius ir somatinius negalavimus. Tarp mažai fiziškai aktyvių tiriamujų (vyrų ir moterų) pastebimas statistiškai patikimas skirtumas jiems nusakant tokius savo negalavimus: galvos skausmą, greitą širdies plakimą ir galvos svaigimą bei nugaros skausmus. Idomu, kad minèto fizinio aktyvumo grupès moterims būdingi ir kiti negalavimai: nerimas, depresiškumas, sprando ar peties skausmai. Beveik toks pat procentas mažai fiziškai aktyvių ir aktyvių moterų nurodè, kad jas vargina skrandžio negalavimai. Kiek labiau skyrėsi miego sutrikimai.

Tyrimo metu užfiksuota tokia tendencija: fiziškai aktyvesni vyrai $(55,6 \%)$ rečiau nei mažai fiziškai aktyvūs $(66,7 \%)$ patiria nuolatinę ir dažną itampa, kurią sukelia ịvairūs veiksniai. Nustatytas statistiškai reikšmingas skirtumas tarp tokio savijautą apibūdinančio veiksnio kaip įtampa, lyginant fiziškai aktyvesnes $(30,0 \%)$ ir mažai aktyvias $(50,0 \%)$ moteris $(\mathrm{p}<0,01)$.

Idomus faktas, kad fiziškai aktyvūs vyrai dažniau nei mažai aktyvūs rūko kasdien (36,8 ir 16,7\%; $\mathrm{p}<0,01)$. Tokia tendencija pastebima ir tarp moteru $(20,0$ ir $12,5 \% ; p<0,1)$.

Palyginus fizinio aktyvumo duomenis su tiriamuju nuomone apie tai, kaip jie vertina savo gyvenimą lygindamiesi su dauguma Lietuvos šeimu, pastebèta, kad fiziškai aktyvesni vyrai, palyginus su mažiau aktyviais, dažniau nurodè, kad jie gyvena taip, kaip dauguma Lietuvos šeimu (90,5 ir $16,7 \% ; p<0,001)$. Mažiau fiziškai aktyvūs vyrai dažniau mano esą turtingesni nei dauguma Lietuvos šeimų $(66,7$ ir 9,5\%; p < 0,001). Tarp moteru pastebimos analogiškos tendencijos (atitinkamai $92,3 \%$ fiziškai aktyvių ir 70,8\% mažai fiziškai aktyvių bei $25,0 \%$ mažai fiziškai aktyvių ir 7,7\% fiziškai aktyvių).

\section{REZULTATU APTARIMAS}

Prieš gilinantis i sąsajas tarp asmens fizinio aktyvumo ir savijautos, dera aptarti fizinio aktyvumo apraiškas apskritai. Europos Sajungos šalyse 2009 metais nesportuojančiu vidurkis buvo 39,0\%, Lietuvoje - 44,0\% (Beveik pusé lietuviu niekada nesportuoja - apklausa, 2010). Dauguma $(61,0 \%)$ Lietuvos gyventoju sportuoja norèdami pagerinti savo savijautą ir dažniau nei dauguma Europos Sajungos šalių atstovų nurodé, kad sportas jiems - pramoga, rečiau nei kiti būdas atsipalaiduoti, kontroliuoti svorí, laikas, kuri gali praleisti su draugais. Minètasis tyrimas atskleide, kad Lietuvoje yra bene mažiausiai sporto, sveikatingumo ar socialinių-kultūriniu klubu su sporto elementais lankytojų. Lietuva ir Graikija, kuriose $88 \%$ tiriamujų teigè, kad nelanko jokio sporto klubo, užima antrą ir trečią vietas pagal ši rodikli nuo pabaigos. Beveik pusė lietuvių (47\%) sutiko su teiginiu, kad vietinè valdžia skiria mažai dèmesio savo piliečių fizinio aktyvumo puoselejjimui.

Kaip matyti, šis tyrimas iškelia asmenybinių veiksnių ir makroaplinkos sąsajas. Apie tai rašo ir Brazilijos, kaip vidutiniškų pajamų arba besivystančios šalies, mokslininkai (Reichert et al., 2007). Nors yra žinoma fizinio aktyvumo verte asmenybės savijautai, tačiau plinta fizinis pasyvumas. Suaugusiujų nurodomos aplinkos ir asmenybinès kliūtys dèl fizinio aktyvumo laisvalaikiu yra neigiamai susijusios su fizinio aktyvumo raiška. Tačiau suvokiamos kliūtys ir jų svarba fiziniam aktyvumui priklauso nuo makroaplinkos. Ši teigini paremia N. Cavill ir kolegų (2006) atlikto tyrimo ir jau cituotos Europos Sajungos šalyse vykdytos apklausos duomenys. Europos šalių fizinio aktyvumo analizè rodo, kad Europoje 2002 m. du trečdaliai visu suaugusiujų nepasiekè rekomenduojamo fizinio aktyvumo lygmens. Tyrejai akcentuoja, kad $31 \%$ apklaustujuc dalyvauja rekomenduojamo intensyvumo, dažnumo ir trukmès fizinio aktyvumo veikloje. Skirtingų tradicijų kultūrose pastebima fizinio aktyvumo įvairove, pavyzdžiui, Olandijoje tokiu yra beveik $45 \%$, Vokietijoje - 40\%, Portugalijoje $-34 \%$, Belgijoje $-25 \%$, Švedijoje ir Prancūzijoje - apie 24\%. Palyginus $2002 \mathrm{~m}$. ir 2009 m. apklausos rezultatus matyti, kad fiziškai pasyviu suaugusiujų padaugèjo.

Tokia situacija skatina vèl akcentuoti makroaplinkos veiksnius dèl fizinio aktyvumo, pvz.: bendrą šalies socialinę-konominę padètị, kultūrines ir klimatines sąlygas. Fizinis aktyvumas ir sportavimas, pasak N. W. Burton ir G. Turell (2000), nepaaiškinamas tokiais mikroaplinkos veiksniais kaip gyvenimo ir darbo aplinka, socialiniu normu laikymasis ir vietos bendruomenè. Australijoje apklausus dirbančius asmenis ir juos suskirsčius pagal darbo valandu per savaite skaičiu bei atlikus vyru ir moteru logistine regresine analizę atskirai gauta, kad beveik $50 \%$ darbininku yra mažiau fiziškai aktyvūs laisvalaikiu nei ịvairiu sričiu profesionalai ir tarnautojai. Teigiama, kad toki fizinio aktyvumo laisvalaikiu paplitimą tarp skirtingos profesinès veiklos asmenų nepaaiškina jų darbo valandų skaičius per savaitę.

Vokietijoje S. Schneider ir S. Becker (2005) taip pat gilinosi i fizinio aktyvumo paplitimą tarp dir- 
bančių asmenų bei domėjosi, kokie darbo veiksniai ir profesinès veiklos ypatumai turi įtakos asmens fiziniam aktyvumui. Atskleista, kad 39,2\% dirbančiujų nesportuoja, nesimankština. Nurodoma, kad sunkų fizinį darbą atliekantys ir dažnai viršvalandžius dirbantys asmenys statistiškai reikšmingai, lyginant su kitais, būna mažiau fiziškai aktyvūs laisvalaikiu. Pažymima, kad ne fizinio darbo atstovai, jauni ir viengungiai, dažniau nei kiti renkasi aktyvias laisvalaikio praleidimo formas. Teigiama, kad tiriamieji neatitiko populiaraus rekreacinio poilsio atleto îvaizdžio - abstinentas, asketas. Mat nerūkančiujų ir blaivininkų subgrupèse statistiškai reikšmingai rečiau buvo tokių, kurie sportavo, mankštinosi. Tyrimas atkreipia dèmesį i mažai fiziškai aktyvius asmenis laisvalaikiu, t. y. į dirbančius sunkų fizini darbą ir turinčius žemesni nei vidurinis išsilavinimą. Kitaip tariant, i tuos, kurie priklauso visuomenès žemesnèms socialinėms-ekonominėms grupėms. Tyrèjai teigia, kad jų rezultatus patvirtina ir kitų šalių mokslininkų išvados.

Straipsnyje aprašomame tyrimo Lietuvos PnTI ugdytojus galima ịvardyti kaip šalyje besiformuojančios vidurinès klasės atstovus (Matulionis ir kt., 2005). Mat tiek vidurinèje, tiek žemesniojoje socialinejje-ekonominèje klasèje yra tokias pačias pajamas gaunančiuc, t. y. palyginti mažai uždirbančių žmonių, todèl tik išsilavinimas ir kultūrinè aplinka leidžia kalbèti apie ugdytojus kaip viduriniosios klasès atstovus. Tokia sociologinè pozicija rodo, kad tiriamujų fizinis aktyvumas patvirtina socialinio-ekonominio statuso ir fizinio aktyvumo laisvalaikiu sąsajas. Ši ryši atskleide ir Japonijoje atliktas tyrimas apie fizinio aktyvumo paplitimą tarp skirtingos profesinès veiklos asmenu. Nustatyta, kad fizinis aktyvumas laisvalaikiu statistiškai patikimai skiriasi pagal darbinès veiklos pobūdi (Takao et al., 2003). Pažymima, kad įstaigos tarnautojai yra fiziškai aktyvesni laisvalaikiu nei vadovai ir darbininkai. Rezultatai nesiskyrè lyginant tiriamuosius pagal tokius socialinius demografinius ypatumus kaip išsilavinimas, amžius ir darbo valandos. Autoriai pažymi, kad nustatyti skirtumai dèl fizinio aktyvumo laisvalaikiu tarp moteru pagal darbinès veiklos pobūdi nèra statistiškai reikšmingi. Fiziškai aktyvesni tie tiriamieji, kurie pagal darbinès veiklos pobūdi priskiriami viduriniam socialiniamekonominiam visuomenès sluoksniui, t. y. klerkai. Palyginus fizinio aktyvumo laisvalaikiu duomenis su tiriamujų savijauta atskleista, kad vidurinio socialinio-ekonominio visuomenès sluoksnio atstovai rečiau miršta nuo širdies ir kraujagyslių ligų, ypač tokia situacija būdinga vyrams.
Pateiktoji duomenu interpretacija rodo, kad skirtingos raidos šalyse asmenys, būdami tam tikro veiksnumo, ivvairiai ịsitraukia ir i fizinị aktyvumą laisvalaikiu. Mat modifikuoti tokius aktyvios gyvensenos laisvalaikiu determinantus kaip šalies klimatas ar žmogaus genotipas yra sunku, tiksliau - beveik neįmanoma. Todèl žvelgiant i TnPI ugdytoju fizinio aktyvumo ir savijautos sąsajas teigtina, kad rezultatai galèjo būti lemti Lietuvos situacijos, susidariusios kuriant liberalią demokratinę valstybę, o ne asmenybinių veiksnių nuostatos dél fizinio aktyvumo, tikejjimo savo fiziniais gebejjimais ir noro išbandyti naują veiklą. Šią prielaidą deretuc patikrinti tolesniais tyrimais, o dabar ši teigini galima paremti duomenimis apie PnTI ugdytojų socialinę savijautą.

Abiejose fizinio aktyvumo grupėse PnTI ugdytojams būdingas nerimas, galvos svaigimas, greitas širdies plakimas, depresiškumas. Tai rodo, kad fizinis aktyvumas, kaip sveikatos riziką mažinanti veikla, šioje socialinèje-ekonominèje situacijoje nèra geros savijautos pagrindas. Be to, ir tarp patiriamos įtampos dažnio skirtingo fizinio aktyvumo vyrų grupėse nėra statistiškai reikšmingo skirtumo. Šio tyrimo metu, kaip ir anksčiau cituoto - atlikto Vokietijoje (Schneider, Becker, 2005) - fiziškai aktyvūs ugdytojai dažniau rūkẻ kasdien nei mažai fiziškai aktyvūs tiriamieji. Rūkymas ir kaip bendravimo forma, ir kaip neigiamas sveikatos veiksnys dominuoja tarp vyrų, ypač tarp fiziškai aktyvių. Tokią situaciją galima aiškinti visuomenès požiūriu į vyriškumą, kuris dažnai tapatinamas su jèga, dominavimu (Johannesen-Schmidt, Eagly, 2002), o Lietuvoje iš daugialypio tradicinio vyro vaidmens, kuris rèmèsi įvairiais gynejo, šeimos atstovo, autoriteto, globejjo ir kt. gebejjimais, dabar dažniausiai vyrai renkasi duonpelnio vaidmeni (Navaitis, 2007). Be to, rūkymas padeda bendrauti tada, kai moterys dalijasi emocijomis, informacija, o vyrams svarbiau patarti i juos besikreipiantiems pagalbos, siekiant šių asmenų ir apskritai su jais bendraujančiu pripažinimo.

Vokietijoje atlikto tyrimo tarp skirtingu profesijų asmenų rezultatai kreipia dèmesi i tai, kad laisvalaikiu fiziškai aktyvūs asmenys nuo mažai fiziškai aktyvių skiriasi išsilavinimu, o skirtumu nèra nei pagal amžių, nei pagal lyti, nei pagal rūkymą ar sveikatą apskritai. Kadangi PnTI ugdytojai - aukštajj universitetinį išsilavinimą turintys asmenys ir labiau protinès nei fizinès profesinès veiklos atstovai, besirūpinantys sveikata, fiziškai aktyviai leidžiantys laisvalaikị ir gyvenantys kaip dauguma šeimų Lietuvoje, tai galima kalbėti apie 
juos kaip apie viduriniają visuomenès socialinęekonominę klasę. Toks įvardijimas leidžia gautas fizinio aktyvumo ir finansinès padeties sąsajas komentuoti ir pagal kitų tyrèjų išvadas, ir pagal jų nurodytas fizinio aktyvumo laisvalaikiu kliūtis. Asmens įsitraukimo į fizinį aktyvumą laisvalaikiu dažnio analizè rodo, kad Anglijoje (Allender et al., 2008), kaip vienoje iš gerovès valstybių, iš bendrojo fizinio aktyvumo eliminavus fizini aktyvumą profesinèje veikloje, nèra statistiškai patikimo skirtumo tarp dirbančiujų, kurie turi edukacini laipsni (26\%), ir nekvalifikuotuc (25\%). Rezultatai socialiai svarbūs, nes dèl fizinio aktyvumo laisvalaikiu nèra skirtumo pagal amžių ir lyti, o tik iš asmens bendrojo fizinio aktyvumo ir jo fizinio aktyvumo profesinejje veikloje aiškejja, kad vyrai fizinio darbo atstovai - yra fiziškai aktyvesni nei tie, kurie dirbo priešingo pobūdžio darbą. Visgi kai buvo eliminuotas fizinis aktyvumas profesinèje veikloje, tai asmenu fizinis aktyvumas nesiskyrè. Panašūs rezultatai ir moteru grupejje. Socialinis statusas yra daugmaž tiesiogiai susijęs su fizinio aktyvumo rekomendacijomis skirtingose amžiaus grupèse. Aiškus fizinio aktyvumo sumažèjimas pastebimas tarp vyrų, ypač tarp tų, kurie vyresni nei 65 metu. Cituojami autoriai atkreipia demesi i toki fakta, kad žmonès siekia pagerinti savo fizinio aktyvumo rodiklius. Autoriai mano, kad jų tiriamieji galejo padidinti fizini aktyvumą profesinejje veikloje, nes kartais tie, kurie savo užsièmimą pažymėjo kaip aktyvų, realybėje galèjo būti mažai fiziškai aktyvūs savo darbe, pavyzdžiui, statybos aikštelès vadybininkas save priskyre statybininkų grupei. Tokị aiškinimą diktuoja kitų tyrejų išvados apie Anglijos piliečių fizini aktyvumą, kurios aktualios ir dèl PnTI ugdytojų fizinio aktyvumo. Mat atskleista, kad fiziniam aktyvumui laisvalaikiu vis daugiau dèmesio skiria tokie Anglijos piliečiai, kurių fizinis aktyvumas profesinejje veikloje mažèja, bet auga ju socialinis-ekonominis statusas (Macintyre, Mutrie, 2004).

Skirtingų socialinių bei kultūrinių sąlygų itaką asmenu fiziniam aktyvumui iliustruoja ir JAV atliktas tyrimas. Atskleista, kad nèra sąsaju tarp išsilavinimo bei fizinio aktyvumo laisvalaikiu, ir tai prieštarauja kitų tyrejų išvadoms (Wollin, Bennett, 2008), o išsilavinimas neigiamai susijęs su fiziniu aktyvumu profesineje veikloje. Mat šis aktyvumas daug svarbesnis dèl asmens fizinio aktyvumo laisvalaikiu nei jo išsilavinimas, o ypač tai būdinga vyrams. Kadangi cituojamų autoriu išvados kontroversiškos kitų tyrimų požiūriu, tai tyrèjai šį faktą komentuoja taip: sunkiai dirbantys asmenys gali būti fiziškai aktyvūs laisvalaikiu todèl, kad jų laisvalaikis padeda jiems iveikti ir fizinius, ir emocinius profesinès veiklos reikalavimais. Gerèjantis fizinis pajègumas ir fizinè būklè tų, kurie fiziškai aktyvūs profesinèje veikloje, gali palengvinti ju gebejjima užsiimti fiziškai aktyvia veikla laisvalaikiu (ir skatinti juos įsitraukti į fizinio aktyvumo užsièmimus). Be to, kai kuri profesiné veikla, reikalaujanti didelio fizinio aktyvumo, aukštų socialinių normų, gali egzistuoti dèl dalyvavimo grupine veikla pagristo fizinio aktyvumo laisvalaikiu (pvz., neformalūs sportiniai žaidimai pramogaujant, atletų sajunga, senjoru žaidynės). Kita vertus, autoriai mano, kad tiriamieji galejjo ir ne taip užfiksuoti atliekamą profesinę veiklą. Tyrejjai pažymejjo, kad faktas apie teigiamą ryši tarp fizinio aktyvumo profesineje veikloje ir aktyvumo laisvalaikiu nėra fiksuotas tarp tų tiriamujų, kurių išsilavinimas žemesnis nei vidurinis. Gautą išvada, kad nèra sąsajų tarp išsilavinimo ir fizinio aktyvumo laisvalaikiu, galima aiškinti taip: darbininkais JAV dirba ir baigusieji koledžą, ir universitetą. Akcentuojama, kad moterų grupeje taip pat nèra sąsajų tarp išsilavinimo ir fizinio aktyvumo laisvalaikiu. Visgi jų fizinio aktyvumo dažni, trukmę ir intensyvumą lemia ịvairūs socialiniai veiksniai, ypač pareigos šeimoje. Sistemine tyrimu analize apie fizinio aktyvumo ir socialinio-ekonominio statuso sąsajas parodè, kad yra tiesioginis ryšys tarp asmens fizinio aktyvumo ir jo socialinio-ekonominio statuso, t. y. tarp jo pajamų ir išsilavinimo (Gidlow et al., 2006).

Pateiktieji tyrimai leidžia konstatuoti, kad PnTI ugdytojų darbas, kaip fizinès ir protinès veiklos simbiozè, skatina rūpintis fiziniu tinkamumu isitraukiant i fiziškai aktyvią veiklą laisvalaikiu. Be to, profesinès veiklos ypatumai: darbo vieta, ugdytiniu charakteristikos, profesijos (policininkai, profesijos mokytojai, ivvairių mokomuju dalyku mokytojai bei visuomenès sveikatos specialistai, psichologas ir kt.) reikalauja iš profesionalu geros sveikatos apskritai. Toks darbas ir socialinis-ekonominis statusas gali turèti titakos tyrimo fizinès savijautos rezultatams (pvz., fiziškai aktyvūs ugdytojai rečiau išgyveno itampą dèl ivairiu gyvenimo veiksniu ir rečiau lankèsi pas gydytoją (išskyrus odontologa), rečiau sirgo peršalimo ligomis taip, kad gulètų lovoje ilgiau nei vieną dieną). Aprašytoji fiziškai aktyvių asmenu savijauta akcentuojama ir kitų autoriu darbuose (Takao et al., 2003; Schneider, Becker, 2005; Warburton et al., 2006).

Lietuviai gyvena (ir gyveno) socialiniu bei kultūrinių vertybių sumaištyje, ekonominių iššūkių 
aplinkoje, todèl PnTI ugdytojų savijauta gerètų dèl jų fizinio aktyvumo, jei didesnę itaką šiam procesui turètų tokie mikroaplinkos veiksniai kaip institucijos ir vietos bendruomenès, vietos bendruomenès socialinė parama bei kultūrinių stereotipu kaita asmeniui renkantis tinkamą mankštinimosi ar sportavimo forma, vietą, laiką, įskaitant ir važiavimą i darbo vietą dviračiu, ejimą pessčiomis ar šiaurietiškai vaikščiojant. Kad ugdytojas galètuc konkrečioje institucijos fizinèje, pragmatinejje bei komunikacineje aplinkoje stiprinti savo atletini tapatumą kaip geros savijautos profesiniame bei asmeniniame gyvenime prielaida - svarbus ir administracijos vaidmuo.

\section{IŠVADOS}

Fiziškai aktyvesni ugdytojai (vyrai ir moterys) iš paauglių tardymo izoliatoriaus ir pataisos namų rečiau nei mažiau aktyvūs išgyvena dèl i̇vairių veiksniu kylančią įtampą, rečiau patiria ivairius psichosomatinius ir somatinius negalavimus bei mano, kad gyvena kaip dauguma šeimu Lietuvoje. Pastarojo teiginio atžvilgiu geriau savo finansinę padèti, lyginant su kitais Lietuvos gyventojais, vertina mažiau fiziškai aktyvūs tiriamieji.

Fiziškai aktyvesnès moterys ir vyrai geriau nei mažiau aktyvūs vertina savo sveikatą, tačiau fiziškai aktyvesni vyrai, skirtingai nei moterys, rečiau linkę ja rūpintis.

Nerastas teigiamas ryšys tarp fizinio aktyvumo ir rūkymo rodo, kad gerinant asmens savijautą, be fizinio aktyvumo, turètu būti taikomos ir kitos sveiką gyvenseną propaguojančios profilaktinio poveikio priemonès. Be to, fizini aktyvumą galima iškelti kaip sèkmingos asmeninès ir profesinès karjeros sąlyga, ypač tai svarbu profesionalams, kurie dèl veiklos specifikos dažnai išgyvena ittampa.

\section{LITERATŪRA}

Allender, S., Foster, Ch., Boxer, A. (2008). Occupational and nonoccupational physical activity and the social determinants of physical activity: Results from the health survey for England. Journal of Physical Activity and Health, 5, 104-116.

Beveik puse lietuviu niekada nesportuoja - apklausa. (2010). BNS.

Brown, J., Fielding, J., Grover, J. (1999). Distinguishing traumatic, vicarious and routine operational stressor exposure and attendant adverse consequences in a sample of police officers. Work and Stress, 3 (4), 312-325.

Buker, H., Wiecko, F. (2007). Are causes of stress global? Testing of the effects of common police stressors on the Turkish National Police. An International Journal of Police Strategies and Management, 30 (2), 291-309.

Burke, R., Mikkelsen, A. (2005). Burnout, job stress and attitudes towards the use of force by Norwegian police officers policing. An International Journal of Police Strategies and Management, 28 (2), 269-278.

Burton, N. W., Turell, G. (2000). Occupation, hours worked, and leisure-time physical activity. Preventive Medicine, 31 (6), 673-681.

Cavil, N., Kahlmeier, S., Racioppi, F. (2006). Physical Activity and Health in Europe: Evidence for Action. WHO Library Cataloguing in Publication Data.

Giddens, A. (1984). The Constitution of Society: Outline of the Theory of Structuration. London: Hutchison.

Gidlow, Ch., Johnston, L. D., Crone, D., Ellis, N., James, D. (2006). A systematic review of the relationship between socioeconomic position and physical activity. Health Education Journal, 65 (4), 338-367.

Johannesen-Schmidt, M., Eagly, A. (2002). Another look at sex differences in preferred mate characteristics: The effects of endorsing the traditional female gender role. Psychology of Women Quarterly, 26, 322-328.

Macintyre, S., Mutrie, N. (2004). Socio-economic dif- ferences in cardiovascular disease and physical activity: Stereotypes and reality. Journal of the Royal Society of Health, 124 (2), 66-69.

Matulionis, A. V., Kasparavičienè, V., Kocai, E. ir kt. (2005). Lietuvos socialinè struktūra. Vilnius: Firidus.

Navaitis, G. (2007). Vyrų nuostatos i saviraišką tėvystejje. Acta Paedagogica Vilnensia, 19, 127-134.

Reichert, F. F., Aluisio, M., Barros, J. D., Domingues, M. R., Hallal, P. C. (2007). The role of perceived personal barriers to engagement in leisure-time physical activity. American Journal of Public Health, 97 (3) 515-519.

Schneider, S., Becker, S. (2005). Prevalence of physical activity among the working populiation and correlation with work-related factors: Results from the first German national health survey. Journal of Occupational Health, 47, 414-423.

Stock, C., Kramer, A. (2000). Psychosoziale belastung und pcychosomatische beschwerden von studierenden. In Sontag, U., Graser, S., Stock, C., Kramer, A. (Hrsg), Gesundheitsfordende hochschulen. Konzepte, strategien und praxisbeispiele. Weinheim und Munchen: Juventa verlag. S. $127-138$.

Takao, S., Kawakami, N., Ohtsu, T. (2003). Occupational class and physical activity among Japanese employees. Social Science and Medicine, 57 (12), 2281-2289.

Warburton, D. E. R., Nicol, C. W., Bredin, S. S. D. (2006). Health benefits of physical activity: The evidence. Canadian Medical Association Journal, 174 (6), 801-809.

Wolin, K. Y., Bennett, G. G. (2008). Interrelations of socioeconomic position and occupational and leisure-time physical activity in the national health and nutrition examination survey. Journal of Physical Activity and Health, 5, 229-241.

Гуревич, М. А., Радиловская, Т. Ю. (2003). Физическая культура в Уральском регионе. Сочиологические исследования, 3 (227), 89-92. 


\title{
INTERACTION BETWEEN PHYSICAL ACTIVITY AND FEELING OF WELL-BEING OF ADOLESCENT INQUEST INFIRMARY AND PENITENTIARY TEACHERS
}

\author{
Laimutė Kardeliené $\dot{1}^{1}$, Donatas Lengvinas ${ }^{2}$, Sandra Bardauskien $\dot{e}^{3}$ \\ Lithuanian Academy of Physical Education ${ }^{1}$, Kaunas, University of Klaipéda ${ }^{2}$, Klaipeda, \\ Kaunas University of Medicine ${ }^{3}$, Kaunas, Lithuania
}

\begin{abstract}
The present study aimed at assessing physical activity of adolescent inquest infirmary and penitentiary teachers and revealing its links with the indices of their well-being. The sample from the whole general population consisted of 84 research participants (31 males and 53 females).

The study employed a questionnaire survey which was meant to reveal the following context of the educators' professional socialization: physical activity in the leisure time, feeling of well-being and financial background. The feelings of well-being were assessed by the subjective evaluation of the respondents' health and willingness to take care of it. There were also questions about smoking and various psychosomatic and somatic ailments which have been occurring for the last 12 months.

Research results revealed that more physically active educators (both males and females) from the adolescent inquest infirmary and penitentiary, compared to their less physically active counterparts, experienced less stress due to various factors, more seldom suffered from psychosomatic and somatic ailments, and they believed that they lived as the majority of families in Lithuania. However, research participants who were less physically active better evaluated their financial conditions.

Physically active males and females attributed higher evaluations to their health, but physically active males compared to females tended to pay less attention to taking care of it. We did not find any positive relation between physical activity and smoking, and it suggests that for the improvement of personal wellbeing other prophylactic means of promoting healthy life style should be applied besides physical activity.
\end{abstract}

Keywords: physical activity, feeling of well-being, health improvement. 